\title{
Physical and Mechanical Properties of Antifungal Ionic Liquid-Incorporated Dental Tissue Conditioner
}

\author{
Kavita Kanjanamekanant, Nareudee Limpuangthip, Mansuang Arksornnukit* \\ Department of Prosthodontics, Faculty of Dentistry, Chulalongkorn University, Bangkok, Thailand \\ Email: *mansuang@yahoo.com
}

How to cite this paper: Kanjanamekanant, K., Limpuangthip, N. and Arksornnukit, M. (2017) Physical and Mechanical Properties of Antifungal Ionic Liquid-Incorporated Dental Tissue Conditioner. Materials Sciences and Applications, 8, 376-388. https://doi.org/10.4236/msa.2017.85026

Received: April 2, 2017

Accepted: May 22, 2017

Published: May 25, 2017

Copyright ( 92017 by authors and Scientific Research Publishing Inc. This work is licensed under the Creative Commons Attribution International License (CC BY 4.0).

http://creativecommons.org/licenses/by/4.0/ (c) (i) Open Access

\begin{abstract}
Denture stomatitis and fungal infection are commonly found in long-time denture wearer. Ionic liquids have been used as plasticizer and also possess antimicrobial activity. In this study, ionic liquid in form of 1-Decyl-3-methylimidazolium chloride was incorporated into tissue conditioner (GC Soft-liner ${ }^{\mathrm{TM}}$ ) to improve antifungal activity. Physical and mechanical properties were evaluated. Compliance was carried out using penetration test according to ISO 10139-1. Weight change, water absorption and solubility were determined by weight measurement. Conventional and nystatin-incorporated tissue conditioner served as controls. Results showed that ionic liquid-incorporated tissue conditioner significantly decreased fungal formation, both in material suspension and on material surface. The penetration depth of all groups tended to reduce over time with no significant difference at each time point. After water immersion, ionic liquid- and nystatin-incorporated tissue conditioner gained weight while conventional group showed weight loss. The percentage of water absorption of conventional group was significantly lower than ionic liquid and nystatin group, while the percentage of water solubility of nystatin group was significantly higher than others. Our work indicated that antifungal ionic liquid-incorporated tissue conditioner met the standard criteria in terms of material compliance. However, further studies including dynamic viscoelastic property are needed before clinical trial or application.
\end{abstract}

\section{Keywords}

Antifungal Activity, Dental Tissue Conditioner, Ionic Liquid, Mechanical Properties, Physical Properties 


\section{Introduction}

One of the main problems occurring in long-term denture wearers is the deposition of plaque on tissue surface of the denture, especially in elderly or disabled person who cannot achieve good oral hygiene. This problem often leads to the infection and inflammation of underneath mucous membrane. The symptom is called "denture stomatitis" and often co-exists with fungal infection especially form Candida albicans [1] [2] [3] [4] [5]. Mechanical and chemical stimuli could trauma oral tissue and accelerated these processes, primarily in immune compromised patients. Despite having obvious signs, patients seldom aware of the abnormalities.

The first choice of denture stomatitis treatment is to remove denture in order that oral tissue can recover into normal condition, along with antifungal drug prescription if the sign of fungal infection is presented [6] [7]. However, removing denture may cause masticatory problem and esthetic concern to the patient. Also, the inflammation usually recurs as the causal microorganism still remains on tissue surface of denture. As a result, dentists always solve this problem by grinding tissue surface of denture and relining it with soft liner or tissue conditioning materials. Nevertheless, the problems still reoccur because of plaque deposition on denture liner. The deposited plaque is difficult to be removed by mechanical or chemical method, as it would cause a distortion of denture liner. Moreover, surface roughness and porosity of denture liner itself increase the amount of deposited microorganisms.

Many studies tried to develop antimicrobial tissue conditioner to help prevent microorganism deposition and decrease denture stomatitis incidences. Antifungal drugs, metal-containing substances, and phytotherapeutic agents were added into tissue conditioning materials to achieve therapeutic outcome [8] [9] [10] [11] [12] [13]. However, the addition of these substances changed the optimal concentration of each composition and might affect the properties of material.

Ionic liquids (ILs), the organic salts composed of organic cation and inorganic anion that are liquid at room temperature, are often used as solvents and additives including plasticizer in polymeric materials. Additionally, many ILs possess antimicrobial activity against both bacteria and fungi [14] [15]. The polymeric materials contained ILs also showed antimicrobial properties [16] [17]. Due to both antifungal and plasticizing effects, our study incorporated ILs into dental tissue conditioner in order to improve antifungal property. At the same time, the physical and mechanical properties of material were expected to be maintained or better.

\section{Materials and Methods}

\subsection{Materials}

Tissue conditioner used in this study was GC Soft-Liner ${ }^{\mathrm{TM}}$. Ionic liquid used was 96 wt\% 1-Decyl-3-methylimidazolium chloride. Nystatin use was 100,000 IU Nystatin oral suspension. Details of materials and chemical agents used are 
shown in Table 1.

\subsection{Antifungal Activity and Cytotoxicity Test}

\subsubsection{Antifungal Activity Assay}

C. albicans ATCC 90028 was used as standard microorganism. It was grown in sabouraud dextrose broth in $5 \% \mathrm{CO}_{2}$ chamber at $37^{\circ} \mathrm{C}$ overnight. Microbial suspension was adjusted to initial concentration of $1 \times 10^{6}$ cells $/ \mathrm{ml}$. Materials were divided into three groups including Soft-Liner (SL), 2.25\% IL-incorporated Soft-Liner (IL), and 0.225 wt\% nystatin-incorporated Soft-Liner (NYS). The concentrations of nystatin and IL were chosen from our pilot study, which indicated antifungal activity against $C$. albicans ATCC 90028. Specimens were prepared into a dimension of 10-mm diameter and 2-mm height. Each of them was placed into 24 -well plate containing $10^{3}$ cells/well $C$. albicans suspension and incubated for $24 \mathrm{~h}$.

For cell count, $100 \mu \mathrm{l}$ of $C$. albicans suspension was removed from each well and serial dilutions with spread plate method were carried out to determine colony-forming unit (CFU). At the same time, each specimen was removed, washed twice with phosphate-buffer saline (PBS), re-immersed in PBS and vortexed for $1 \mathrm{~min}$ to disrupt cell adhesion. The number of $C$. albicans adhered on specimen was also determined using serial dilution and spread plate method. The experiments were performed in triplicate and the percentage of log CFU was calculated using the following formula;

$$
\text { Microbial viability }(\%)=\frac{\text { mean } \log C F U \text { of tested group }}{\text { mean } \log C F U \text { of control group }} \times 100
$$

\subsubsection{Cytotoxicity Evaluation}

Material preparation was similar to antifungal activity testing. L929 mouse fibroblast cell line was cultured in 24-well plate at a concentration of $5 \times 10^{4}$ cells/well. Specimens in each group were immersed in $5.4 \mathrm{ml}$ of Dulbecco's modified Eagle's medium (DMEM) supplemented with $10 \%$ fetal bovine serum, L-glutamine, antibiotics and antimycotic drug. After $24 \mathrm{~h}$ incubation in $5 \% \mathrm{CO}_{2}$

Table 1. Material and chemical agents used in this study

\begin{tabular}{|c|c|c|c|}
\hline $\begin{array}{c}\text { Material/ } \\
\text { Chemical agents }\end{array}$ & Manufacturers & $\begin{array}{l}\text { Batch } \\
\text { number }\end{array}$ & Chemical compositions \\
\hline $\begin{array}{c}\text { Tissue } \\
\text { conditioner } \\
\text { GC Soft-Liner }{ }^{\mathrm{TM}}\end{array}$ & $\begin{array}{l}\text { GC Corporation, } \\
\text { Tokyo, Japan }\end{array}$ & 1402131 & $\begin{array}{l}\text { Powder: } 100 \% \text { polyethyl methacrylate } \\
\text { (PEMA) Liquid: } \\
\text { - } 80.9 \mathrm{wt} \% \text { Butyl } \\
\text { phthalyl buthyl glycolate } \\
\text { - } 4.3 \mathrm{wt} \% \text { Dibutyl phthalate }\end{array}$ \\
\hline Ionic liquid & $\begin{array}{l}\text { Sigma-Aldrich } \\
\text { Company }\end{array}$ & - & $\begin{array}{c}96 \text { wt\% 1-Decyl-3-methylimidazolium } \\
\text { chloride }\left(\mathrm{C}_{14} \mathrm{H}_{27} \mathrm{ClN}_{2}\right), \text { Molecular } \\
\text { Weight } 258.83\end{array}$ \\
\hline $\begin{array}{l}\text { Nystatin oral } \\
\text { suspension: Nyst } \\
\text { Oral }\end{array}$ & $\begin{array}{l}\text { Continental-Pharm } \\
\text { Co., Ltd, Bangkok, } \\
\text { Thailand }\end{array}$ & 001 & Nystatin 100,000 IU \\
\hline
\end{tabular}


chamber at $37^{\circ} \mathrm{C}$, culture medium of L929 was replaced with collected medium from each specimen group. Culture medium with no specimen immersion was used as control. The plate was then incubated for $24 \mathrm{~h}$ prior to cytotoxicity assay. The experiments were performed according to the guideline of ISO 10993-5: Biological evaluation of medical device. Cytotoxicity test was performed using the 3-(4,5-dimethyl-2-thiazolyl)-2,5-diphenyl-2H-tetrazolium bromide (MTT) assay. Viable cells were able to convert yellow MTT solution into purple formazan derivative. Optical density (O.D.) value was detected at $570 \mathrm{~nm}$ using an absorbance microplate reader (BiotekELx800; Biotek Instruments Inc, Winooski, VT, USA). The experiments were performed in triplicate. The percentage of viable cell was calculated via formula;

$$
\text { Viable cell }(\%)=\frac{\text { mean O.D.of tested group }}{\text { mean O.D.of control group }} \times 100
$$

\subsection{Physical and Mechanical Properties Test}

Specimens were divided into 3 groups including conventional Soft-Liner (SL), $2.25 \mathrm{wt} \%$ IL-incorporated Soft-Liner (IL), and $0.225 \mathrm{wt} \%$ nystatin-incorporated Soft-Liner (NYS). Each group consists of six specimens.

\subsubsection{Depth of Penetration Measurement}

The compliance of short-term used soft lining materials was measured using a penetrometer according to ISO 10139-1, a standard criteria for short-term-use dental soft lining material, with some modifications. Mixed tissue conditioner was poured into an acrylic ring (30-mm diameter, 3-mm height) supported underneath by an acrylic plate (square-shaped of $4 \times 4 \mathrm{~cm}, 4$ - $\mathrm{mm}$ height). The specimen was covered with polyester sheet, pressed flush against glass slide for 10 min, and then immersed in deionized water at $37^{\circ} \mathrm{C} \pm 1^{\circ} \mathrm{C}$. Two hours after mixing, a polyester sheet was removed and a vertical rod with 1 -mm diameter cylindrical penetrator (a total mass of $50 \pm 5 \mathrm{~g}$ ) was dropped onto surface of specimen and depth of penetration was recorded in millimeters $(\mathrm{mm})$. Each specimen was indented at 3 different positions, which were $5 \mathrm{~mm}$ apart and apart from mold's margin. The test was repeated at day 3 and 7 after water immersion. The values of mean \pm S.D. $(\mathrm{mm})$ and the percentage of penetration depth at day 3 and 7 after water immersion were calculated.

\subsubsection{Water Absorption, Solubility, and Weight Change Measurement}

Disc-shaped specimens were prepared into a dimension of 30-mm diameter and 2-mm thickness. Two hours after mixing, specimens were removed from the mold and weighed with an analytical balance giving an accuracy of $0.005 \mathrm{~g}$. They were re-weighed at day 3 and 7 after water immersion. At day 7, specimens were removed from water and stored in desiccators containing fresh dry silica gel at $37^{\circ} \mathrm{C}$. They were weighed daily until a constant mass was achieved (until weight change of each specimen was no more than $0.002 \mathrm{~g}$ within 2 consecutive days). The percentages of water absorption, water solubility and weight change were 
calculated as follows;

$$
\begin{aligned}
\text { Water absorption }(\%) & =\frac{(M 2-M 3)}{M 1} \times 100 \\
\text { Water solubility }(\%) & =\frac{(M 1-M 3)}{M 1} \times 100 \\
\text { Weight change }(\%) & =\frac{(M-M 1)}{M 1} \times 100
\end{aligned}
$$

where $\mathrm{M}$ is material's weight after 3 and 7 days of water immersion, M1 is an initial weight before immersion (after preparation), M2 is weight after absorption and desorption, M3 is final weight after desiccation.

\subsection{Statistical Analysis}

For penetration depth, percentage of penetration depth and weight change, data were analyzed by two-way repeated measures ANOVA using Sigma Stat (Sigma Stat, San Jose, CA, USA) to determine whether there was an interaction between the factors of time and type of material. To determine the difference among groups and time period, Kruskal-Wallis one-way ANOVA with a posthoc analysis of Tukey Test was used $(p<0.05)$. For water absorption and solubility, data was analyzed by one-way ANOVA with Tukey post-hoc analysis $(p<0.05)$.

\section{Results}

\subsection{Antifungal Activity and Cytotoxicity Evaluation}

The antifungal activity was evaluated by examining the percentage of log colony forming unit (\% $\mathrm{CFU}$ ) of $C$. albicans in suspension and on materials. The number of viable fungal cells in suspension (Figure 1(a)) and the number of adhered fungal cells on material (Figure 1(b)) of IL and NYS groups were significantly decreased compared to conventional SL group. No significant differences between IL and NYS group in both experiments were observed. Cytotoxicity test was performed using MTT assay. There were no significant differences in percent cell viability among conventional SL and NYS group, whereas the value of IL group was significant decreased (Figure 2).

\subsection{Depth of Penetration}

Penetration depth at baseline (day 0), day 3 and day 7 after water immersion of IL group was not significantly different from NYS and conventional SL group at each time point. The depth of all groups was continuously reduced after water immersion, with significant difference at day 7 compared to baseline in all groups (Figure 3). The percentage of penetration depth tended to reduce over time. In both IL and conventional SL groups, the value was significant decreased at day 7 compared to baseline. In NYS group, the percentage of penetration depth was significantly reduced since day 3 (Figure 4 ).

\subsection{Water Absorption, Solubility, and Weight Change}

SL group showed weight loss overtime, though no significant difference was ob- 
served among groups. In contrast, the weight of IL and NYS groups were significantly increased at day 7, compared to baseline (Figure 5). The percentage of water absorption of IL and NYS groups were significantly higher than that of SL (Figure 6), whereas the percentage of water solubility of NYS group was highest among others (Figure 7).

\section{Discussion}

In this study, tissue conditioning material GC Soft-Liner ${ }^{\mathrm{TM}}$ (SL) was chosen due to its availability and popularity among tissue conditioner used in Thailand. Its biocompatibility, physical and mechanical properties have been studied [18] [19] [20] [21]. In order to improve antifungal activity of conventional tissue conditioner, $2.25 \mathrm{wt} \%$ Ionic liquid (IL) were incorporated. Results showed that IL significantly reduced the number of colony formation of $C$. albicans, in both suspension and on SL surface. The antifungal potential was quite similar to

\section{\% CFU (Suspension)}

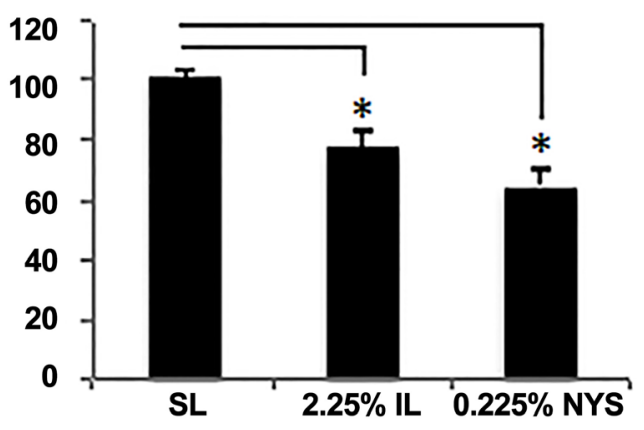

(a)

\section{\% CFU (Material)}

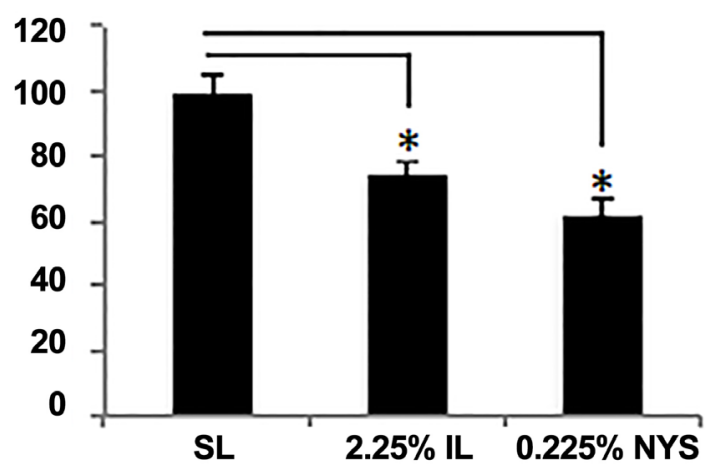

(b)

Figure 1. The percentage of colony forming unit (\%CFU) of C. albicans from material suspension (a) and adhered fungal cells on materials (b). Significant decrease in fungal cell viability was observed in both IL and NYS group, compared to control. Similar results was observed from both suspension and adhered fungal cells. ${ }^{\star}$ Significant difference, $p<0.05$. 


\section{\% Cell viability (MTT)}

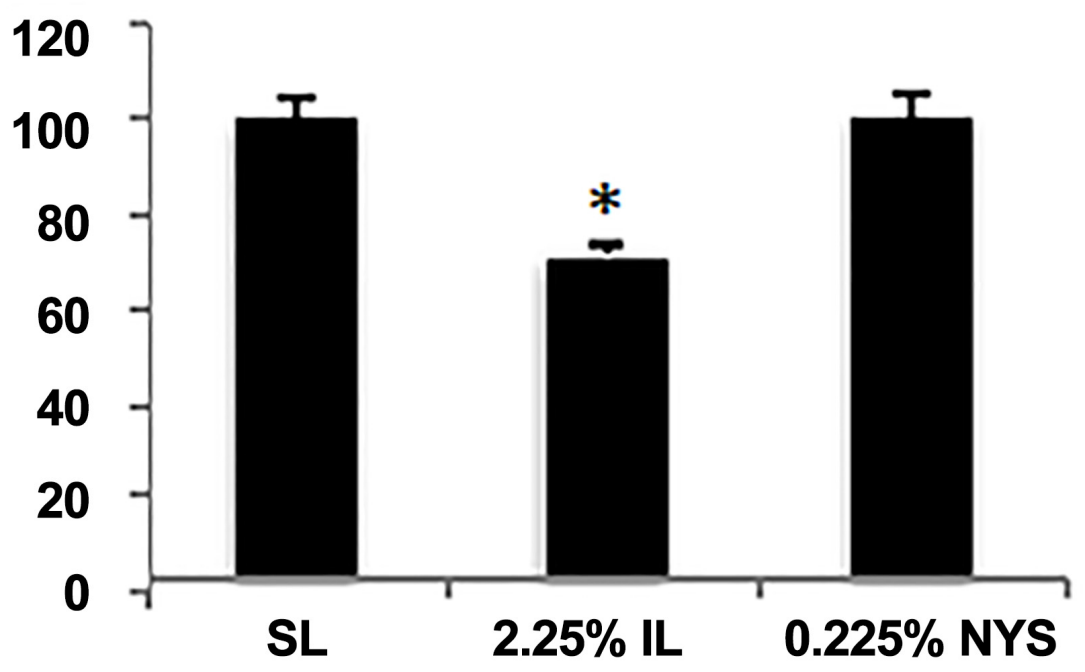

Figure 2. Cytotoxicity test. MTT assay showed significant decrease in L-929 cell viability from IL group, compared to others. ${ }^{\star}$ Significant difference, $p<0.05$.

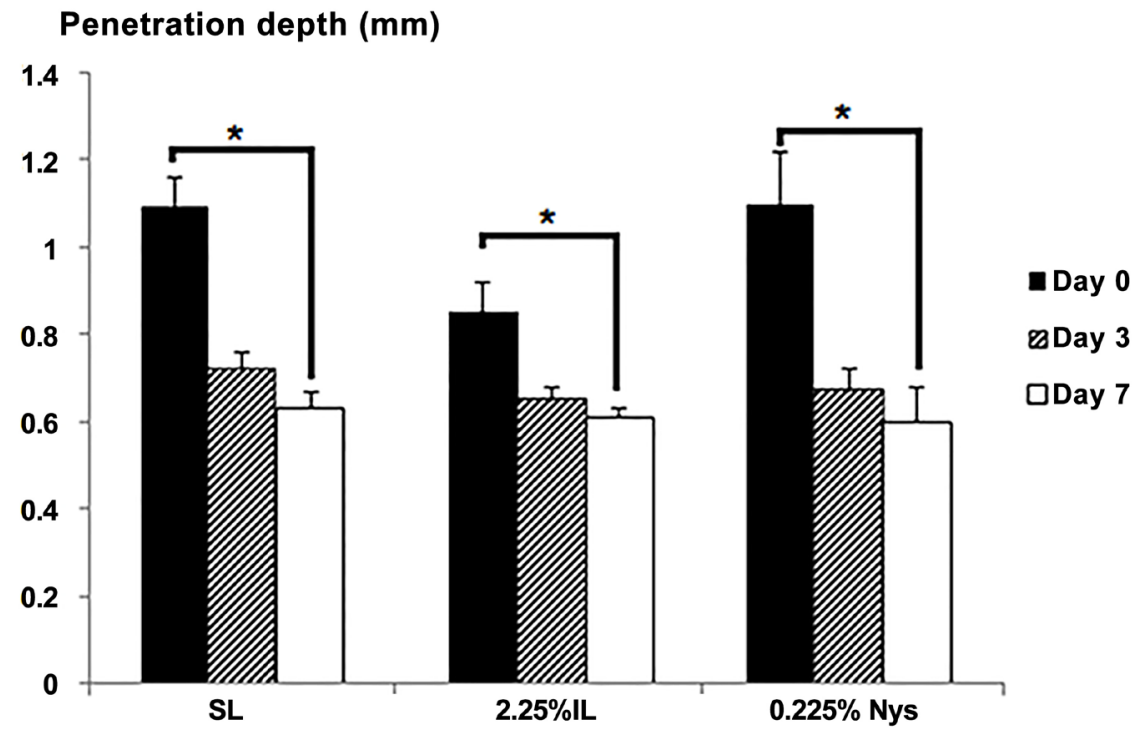

Figure 3. Changes in penetration depth $(\mathrm{mm})$ of tested materials over water-storage time. ${ }^{\star}$ Significant difference, $p<0.05$.

nystatin, a well-known and widely used antifungal drug. Although cell viability test showed more toxic effects to normal cells compared with nystatin, our study indicated that ionic liquid could be used to increase antifungal activity of tissue conditioning material.

Nystatin is the polyenes macrolide biosynthesized by the growth of bacterial strain, Streptomyces noursei. It is active against a wide range of yeasts and yeastlike fungi, including $C$. albicans. The antifungal effect of nystatin is from the 
ability to specifically attack fungal cell. Human or animal cell membranes composed of phospholipid bilayers, with cholesterol as an essential component to maintain structural integrity. On the contrary, fungal cells composed of a specific sterol called ergosterol. Nystatin effectively bind to ergosterol, inducing membrane pore formation and changing in membrane permeability, resulting in leakage of intracellular components including potassium ion, leading to acidification of fungal cell and cell death [6] [7] [22].

Ionic Liquids (ILs) are organic salts that are liquid at room temperature, typically composing of bulky organic cations and inorganic anions. In this study, ionic liquid in form of 1-Decyl-3-methylimidazolium chloride were used (Figure 8). Some ILs structures possess antimicrobial activity, which mainly depends

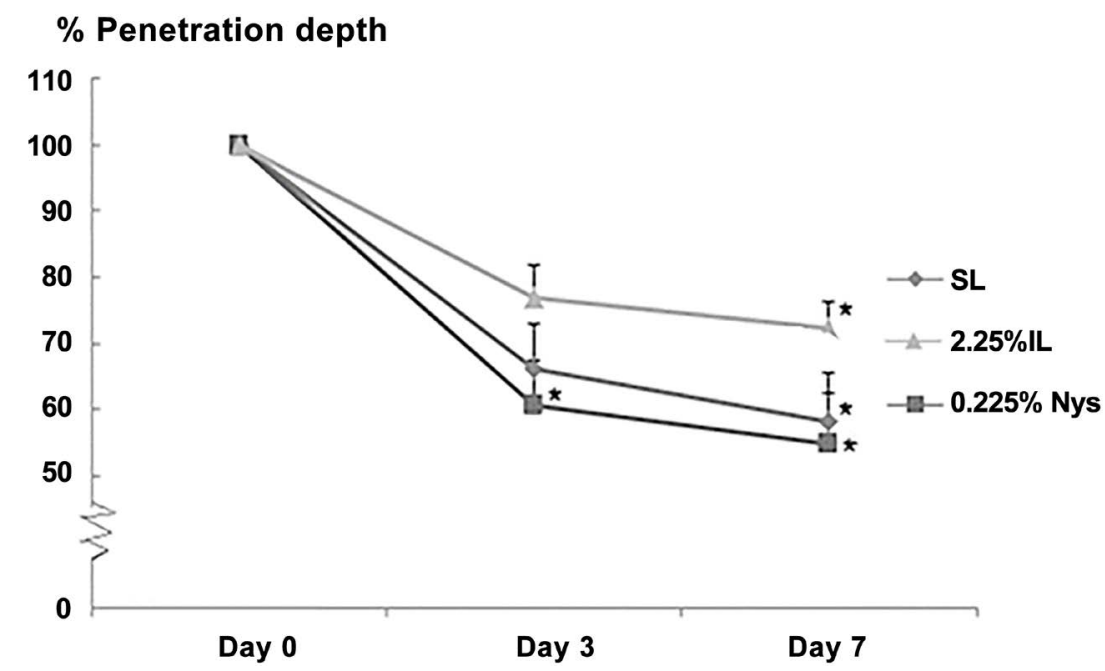

Figure 4. Changes in percentage of penetration depth of tested materials over waterstorage time. ${ }^{\star}$ Significant difference, $p<0.05$.

\section{$\%$ weight change}

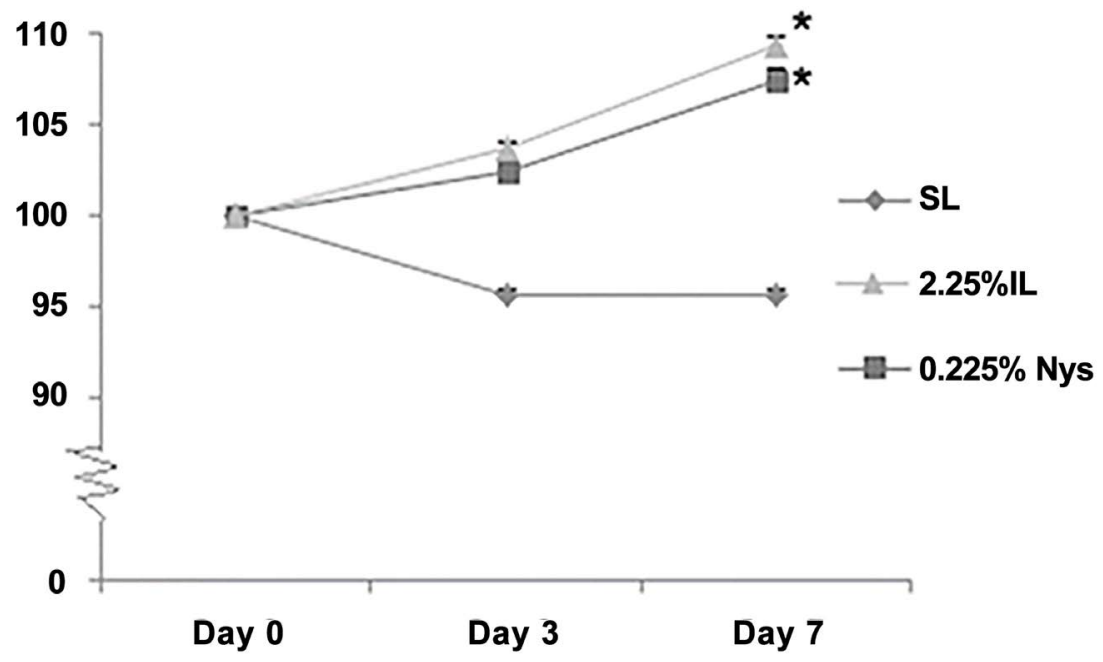

Figure 5. The percentage of weight change of tested materials over water-storage time. ${ }^{\star}$ Significant difference, $p<0.05$. 


\section{$\%$ Water absorption}

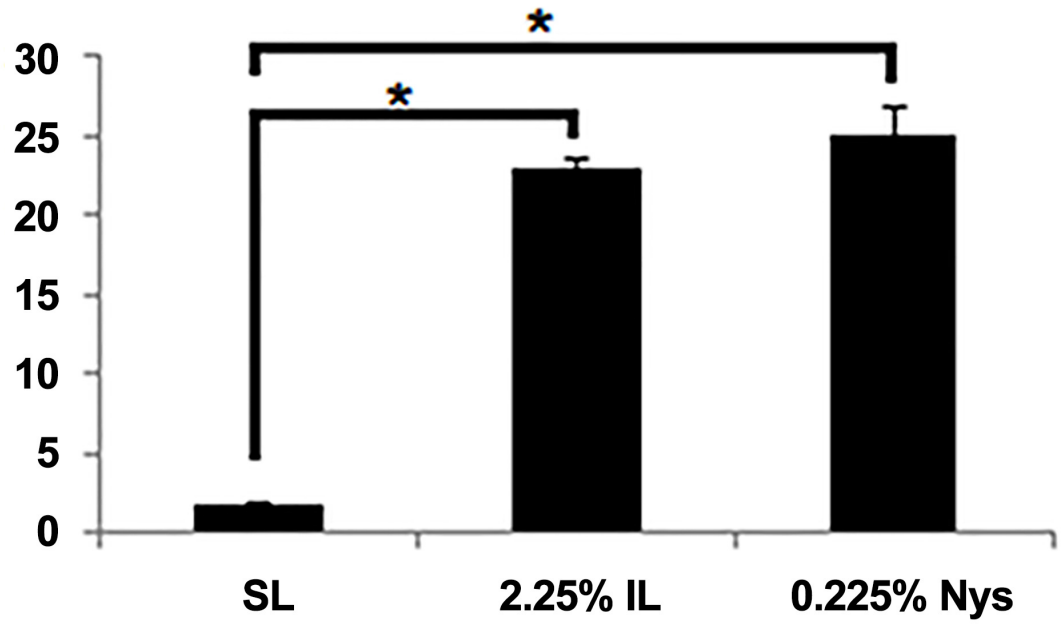

Figure 6. The percentage of water absorption of tested materials. ${ }^{\star}$ Significant difference, $p<0.05$.

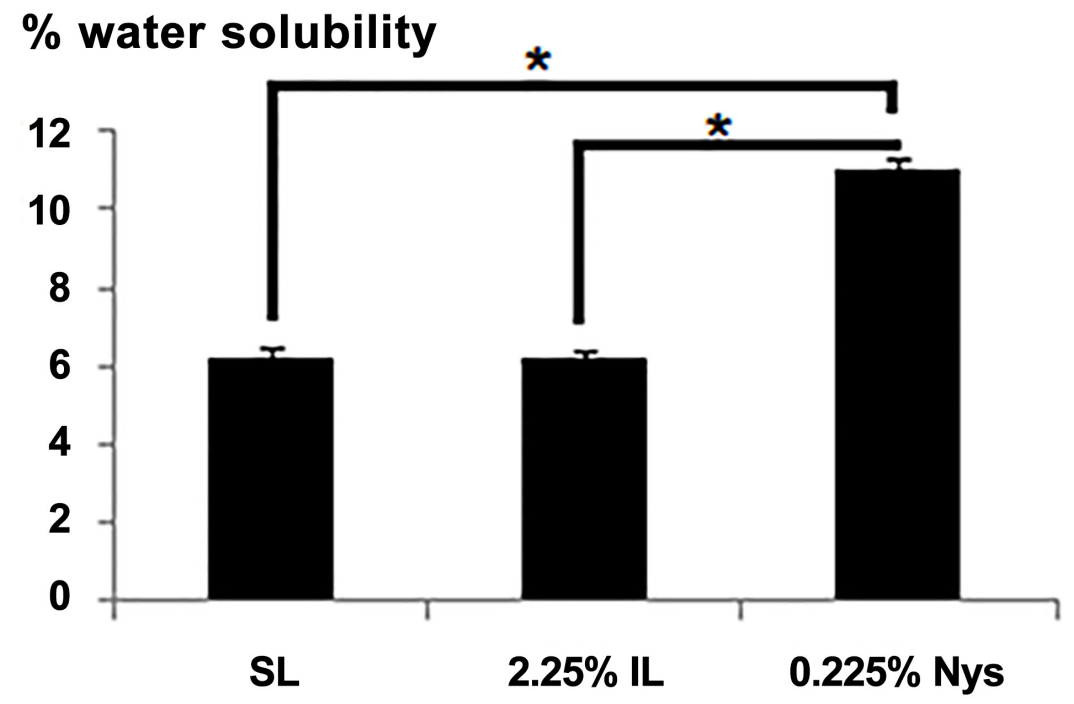

Figure 7. The percentage of water solubility of tested materials. ${ }^{*}$ Significant difference, $p$ $<0.05$.

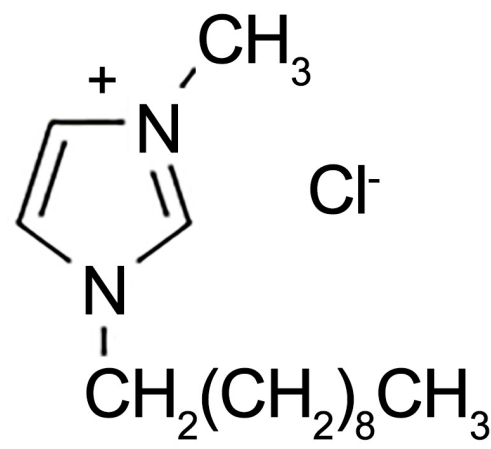

Figure 8. Structure of 1-Decyl-3-methylimidazolium chloride (Sigma-Aldrich ${ }^{\circledR}$ ). 
only on the cationic structure [23] [24] [25] [26]. The positive charges of ILs interact with negative charges of acidic phospholipids in microbial cell membrane, inducing the integration of hydrophobic tail of ILs into hydrophobic microbial membrane core. ILs at high concentration solubilized hydrophobic cell membrane components, forming mixed micellar aggregates and causing disruption of cell membrane. These events lead to denaturation of structural proteins, leakage of intracellular components and cell death [27].

Although both nystatin and IL showed antifungal activity by disrupting fungal cell membrane and cell death. Our study found that even though IL group showed similar antifungal effect to NYS group, more cytotoxicity to normal cell was observed. It is possible that, unlike nystatin which specifically attack sterol of fungal cell, the effect of IL on solubilizing cell membrane component might cause damage to human cell as well. Further study is needed to clarify this matter.

The application of ILs as additives or plasticizers were involved in several types of polymers, mostly for polymethyl methacrylate (PMMA) and polyvinyl chloride (PVC). Plasticizers are additives that function by embedding themselves in-between polymer chains, making them apart, reduce bonding between chains, and increased free volume and some swelling. These improve flexibility and durability of materials [16] [17] [28]. In our study, we incorporate ILs into tissue conditioner in order to achieve both antifungal activity and function as plasticizer.

According to ISO standard, soft lining material in dentistry was categorized into "long-term" and "short-term" usage. Penetration test was recommended to evaluate the compliance or softness of short-term-use soft lining materials over time. Our study found that compliance of all groups met ISO criteria by which penetration depth was no less than $0.5 \mathrm{~mm}$ at day 7 after water immersion. The deeper the penetration depth, the softer the material. Although there was no significant difference, the initial penetration depth of IL group was less than those of conventional and NYS group. However, the change in penetration depth of IL group overtime was lowest compared to others. This might be the plasticizing effect of IL that penetrated into polymer and maintain flexibility of the material. Results suggested that IL-incorporated SL met the standard, in terms of compliance, to be used as tissue conditioner and short-term soft-liner.

Tissue conditioning material consisted of polymeric powder, mainly polyethylmethacrylate (PEMA), and liquid which was a mixture of plasticizer and ethyl alcohol. After water immersion, water is absorbed into material and, simultaneously, ethyl alcohol and plasticizer were leached out [29]. We found that conventional SL lost weight after water immersion, and the percentage of water absorption was lower than water solubility. It might be that the amount of leached out ethyl alcohol and plasticizer was higher than water absorption. In contrast, IL- and nystatin-incorporated SL gained weight and the percentage of water absorption was higher than water solubility, indicating that the amount of absorbed water might be higher than leached out ethyl alcohol and plasticizer. In 
IL group, the increased water absorption might be partly from the effect of IL as plasticizer. The water solubility of IL group was similar to conventional SL but significantly decreased compared to NYS group, suggesting that active substances remained in the material. It is possible that IL, with both plasticizing and antifungal effect, could be longer retained in soft liner, indicating the potential to be used as long term or sustained release antifungal material.

\section{Conclusion}

The results from this study demonstrated that antifungal IL-incorporated SoftLiner met the standard criteria to be used as tissue conditioner and temporary soft liner, in terms of material compliance. However, the softness of material as measured by penetration test did not mimic oral condition where material must withstand both functional and non-functional forces. Dynamic viscoelastic property of material should be further carried out. In addition, the composition of IL-incorporated soft-liner should be further adjusted to reduce cytotoxicity and improve biocompatibility of material.

\section{Acknowledgements}

This work was supported by Faculty Research Grant (Professorial Grant DRF 57010), Faculty of Dentistry, Chulalongkorn University. The authors would also like to thank Dental Material Research Center and Oral Biology Research Center, Faculty of Dentistry, Chulalongkorn University for the instruments and testing machines.

\section{References}

[1] Budtz-Jorgensen, E. (1978) Clinical Aspects of Candida Infection in Denture Wearers. Journal of the American Dental Association, 96, 474-479. https://doi.org/10.14219/jada.archive.1978.0088

[2] Olsen, I. (1974) Denture Stomatitis. Occurrence and Distribution of Fungi. Actaodontologica Scandinavica, 32, 329-333. https://doi.org/10.3109/00016357409002556

[3] Kulak-Ozkan, Y., Kazazoglu, E. and Arikan, A. (2002) Oral Hygiene Habits, Denture Cleanliness, Presence of Yeasts and Stomatitis in Elderly People. Journal of Oral Rehabilitation, 29, 300-304. https://doi.org/10.1046/j.1365-2842.2002.00816.x

[4] Barbeau, J., Seguin, J., Goulet, J.P., de Koninck, L., Avon, S.L., Lalonde, B., Rompre, P. and Deslauriers, N. (2003) Reassessing the Presence of Candida albicans in Denture-Related Stomatitis. Oral Surgery, Oral Medicine, Oral Pathology, Oral Radiology, and Endodontology, 95, 51-59. https://doi.org/10.1067/moe.2003.44

[5] Rautemaa, R. and Ramage, G. (2011) Oral Candidosis-Clinical Challenges of a Biofilm Disease. Critical Reviews in Microbiology, 37, 328-336. https://doi.org/10.3109/1040841X.2011.585606

[6] Garcia-Cuesta, C., Sarrion-Perez, M.G. and Bagan, J.V. (2014) Current Treatment of Oral Candidiasis: A Literature Review. Journal of Clinical and Experimental Dentistry, 6, e576-582. https://doi.org/10.4317/jced.51798

[7] Lyu, X., Zhao, C., Yan, Z.M. and Hua, H. (2016) Efficacy of Nystatin for the Treatment of Oral Candidiasis: A Systematic Review and Meta-Analysis. Drug Design, Development and Therapy, 10, 1161-1171. https://doi.org/10.2147/DDDT.S100795 
[8] Chow, C.K., Matear, D.W. and Lawrence, H.P. (1999) Efficacy of Antifungal Agents in Tissue Conditioners in Treating Candidiasis. Gerodontology, 16, 110-118. https://doi.org/10.1111/j.1741-2358.1999.00110.x

[9] Quinn, D.M. (1985) The Effectiveness, In Vitro, of Miconazole and Ketoconazole combined with Tissue Conditioners in Inhibiting the Growth of Candida albicans. Journal of Oral Rehabilitation, 12, 177-182. https://doi.org/10.1111/j.1365-2842.1985.tb00633.x

[10] Matsuura, T., Abe, Y., Sato, Y., Okamoto, K., Ueshige, M. and Akagawa, Y. (1997) Prolonged Antimicrobial Effect of Tissue Conditioners Containing Silver-Zeolite. Journal of Dentistry, 25, 373-377. https://doi.org/10.1016/S0300-5712(96)00050-4

[11] Nam, K.Y. (2011) In Vitro Antimicrobial Effect of the Tissue Conditioner Containing Silver Nanoparticles. The Journal of Advanced Prosthodontics, 3, 20-24. https://doi.org/10.4047/jap.2011.3.1.20

[12] Sharma, S. and Hegde, V. (2014) Comparative Evaluation of Antifungal Activity of Melaleuca Oil and Fluconazole When Incorporated in Tissue Conditioner: An In Vitro Study. Journal of Prosthodontics: Official Journal of the American College of Prosthodontists, 23, 367-373. https://doi.org/10.1111/jopr.12117

[13] Srivatstava, A., Ginjupalli, K., Perampalli, N.U., Bhat, N. and Ballal, M. (2013) Evaluation of the Properties of a Tissue Conditioner Containing Origanum Oil as an Antifungal Additive. The Journal of Prosthetic Dentistry, 110, 313-319. https://doi.org/10.1016/S0022-3913(13)60381-9

[14] Demberelnyamba, D., Kim, K.S., Choi, S., Park, S.Y., Lee, H., Kim, C.J. and Yoo, I.D. (2004) Synthesis and Antimicrobial Properties of Imidazolium and Pyrrolidinonium Salts. Bioorganic \& Medicinal Chemistry, 12, 853-857. https://doi.org/10.1016/j.bmc.2004.01.003

[15] Ventura, S.P., de Barros, R.L., Sintra, T., Soares, C.M., Lima, A.S. and Coutinho. J.A. (2012) Simple Screening Method to Identify Toxic/Non-Toxic Ionic Liquids: Agar Diffusion Test Adaptation. Ecotoxicology and Environmental Safety, 83, 55-62. https://doi.org/10.1016/j.ecoenv.2012.06.002

[16] Choi, S.Y., Rodriguez, H., Mirjafari, A., Gilpin, D.F., McGrath, S., Malcolm, K.R., Tunney, M.M., Rogers, R.D. and McNally, T. (2011) Dual Functional Ionic Liquids as Plasticisers and Antimicrobial Agents for Medical Polymers. Green Chemistry, 13, 1527-1535. https://doi.org/10.1039/c1gc15132k

[17] Foksowicz-Flaczyk, J. and Walentowska, J. (2013) Antifungal Activity of Ionic Liquid Applied to Linen Fabric. International Biodeterioration \& Biodegradation, 412415. https://doi.org/10.1016/j.ibiod.2012.05.025

[18] Abe, Y., Ueshige, M., Takeuchi, M., Ishii, M. and Akagawa, Y. (2003) Cytotoxicity of Antimicrobial Tissue Conditioners Containing Silver-Zeolite. International Journal of Prosthodontics, 16, 141-144.

[19] Jepson, N.J., McGill, J.T. and McCabe, J.F. (2000) Influence of Dietary Simulating Solvents on the Viscoelasticity of Temporary Soft Lining Materials. The Journal of Prosthetic Dentistry, 83, 25-31. https://doi.org/10.1016/S0022-3913(00)70085-0

[20] Murata, H., Kawamura, M., Hamada, T., Saleh, S., Kresnoadi, U. and Toki, K. (2001) Dimensional Stability and Weight Changes of Tissue Conditioners. Journal of Oral Rehabilitation, 28, 918-923. https://doi.org/10.1046/j.1365-2842.2001.00736.x

[21] Park, S.K., Lee, Y.K., Lim, B.S. and Kim, C.W. (2004) Changes in Properties of Short-Term-Use Soft Liners after Thermocycling. Journal of Oral Rehabilitation, 31, 717-724. https://doi.org/10.1111/j.1365-2842.2004.01294.x 
[22] Kinoshita, H., Yoshioka, M., Ihara, F. and Nihira, T. (2016) Cryptic Antifungal Compounds Active by Synergism with Polyene Antibiotics. Journal of Bioscience and Bioengineering, 121, 394-398. https://doi.org/10.1016/j.jbiosc.2015.08.003

[23] Sharma, A., Prakash, P., Rawat, K., Solanki, P.R. and Bohidar, H.B. (2015) Antibacterial and Antifungal Activity of Biopolymers Modified with Ionic Liquid and Laponite. Applied Biochemistry and Biotechnology, 177, 267-277. https://doi.org/10.1007/s12010-015-1727-7

[24] Pernak, J., Sobaszkiewicz, K. and Mirska, I. (2003) Anti-Microbial Activities of Ionic Liquids. Green Chemistry, 5, 52-56. https://doi.org/10.1039/b207543c

[25] Carson, L., Chau, P.K.W., Earle, M.J., Gilea, M.A., Gilmore, B.F., Gorman, S.P., McCann, M.T. and Seddon, K.R. (2009) Antibiofilm Activities of 1-Alkyl-3-Methylimidazolium Chloride Ionic Liquids. Green Chemistry, 11, 492-497.

https://doi.org/10.1039/b821842k

[26] Busetti, A., Crawford, D.E., Earle, M.J., Gilea, M.A., Gilmore, B.F., Gorman, S.P., Laverty, G., Lowry, A.F., McLaughlin, M. and Seddon,. K.R. (2010) Antimicrobial and Antibiofilm Activities of 1-Alkylquinolinium Bromide Ionic Liquids. Green Chemistry, 12, 420-425. https://doi.org/10.1039/b919872e

[27] Gilbert, P. and Moore, L.E. (2005) Cationic Antiseptics: Diversity of Action under a Common Epithet. Journal of Applied Microbiology, 99, 703-715. https://doi.org/10.1111/j.1365-2672.2005.02664.x

[28] Scott, M.P., Rahman, M. and Brazel, C.S. (2003) Application of Ionic Liquids as Low-Volatility Plasticizers for PMMA. European Polymer Journal, 39, 1947-1953. https://doi.org/10.1016/S0014-3057(03)00129-0

[29] Braden, M. and Causton, B.E. (1971) Tissue Conditioners. 3. Water Immersion Characteristics. Journal of Dental Research, 50, 1544-1547. https://doi.org/10.1177/00220345710500063001

\section{Submit or recommend next manuscript to SCIRP and we will provide best} service for you:

Accepting pre-submission inquiries through Email, Facebook, LinkedIn, Twitter, etc. A wide selection of journals (inclusive of 9 subjects, more than 200 journals) Providing 24-hour high-quality service User-friendly online submission system Fair and swift peer-review system Efficient typesetting and proofreading procedure Display of the result of downloads and visits, as well as the number of cited articles Maximum dissemination of your research work

Submit your manuscript at: http://papersubmission.scirp.org/ Or contact msa@scirp.org 